УДК 343.359.3(477)

I.В. СМЧЕНКО

Львівський торговельно-економічний університет

\title{
ТОВАРНА НОМЕНКЛАТУРА КОНТРАБАНДИ ТА ШЛЯХИ ЇЇ ПОПЕРЕДЖЕННЯ
}

\author{
И.В. ЕМЧЕНКО \\ Львовский торгово-экономический университет \\ ТОВАРНАЯ НОМЕНКЛАТУРА КОНТРАБАНДИ И ПУТИ ЕЕ \\ ПРЕДУПРЕЖДЕНИЯ
}

\section{I.YEMCHENKO}

Lviv university of Trade and Economics

\section{PRODUCT NOMENCLATURE OF CONTRABAND AND WAYS OF ITS PREVENTION}

\section{https://doi.org/10.36910/6775-2310-5283-2020-13-10}

Мета. Визначення чинників, щуо сприяють завезенню товарів контрабандним шляхом з певних країн. Виявлення обставин, що створюють підгрунтя для появи ризикових категорій товарів. Встановлення груп товарів, щэо $\epsilon$ потенційно небезпечними щэодо потрапляння їх на товарний ринок в різних краӥнах світу за існуючими на даний час контрабандними схемами.

Методика. При дослідженнях використовували методи на основі системного аналізу статистичних даних. Для підведення підсумків роботи використовували методи аналізу та синтезу інформації, абстрагування та групування.

Результати. Проаналізовані дані контрабандних поставок товарів в розрізі окремих груп і країн. Представлені дані щзодо фактів виявлення і вилучення контрабандних партій товарів, наркотичних засобів за останні роки. Окреслені основні схеми завезення товарів в Украӥну контрабандним шляхом. Представлені чинники, щуо впливають на зростання обсягів нелегального ринку товарів, та методи $і$ способи потрапляння їх на митні території держав. Наведені сучасні тенденції формування та розвитку нелегального товарного ринку різних держав світу, зокрема України. Наукова новизна одержаних результатів полягає у критичному аналізі иляхів переміщення товарів через митний кордон та потрапляння їх на товарний ринок різних краӥн, зокрема Украйни. Проведено аналіз найбільш поширених схем завезення в держави товарів контрабандним шляхом. Встановлено категорії товарів, щчо стають найчастіше об’єктами контрабандних операиіiй.

Практична значимість полягає у визначенні проблемних питань та встановленні сукупності чинників, щзо формують потенційну небезпечність товарної контрабанди для 
економіки держави. Окреслені заходи протидії контрабанді товарів і порушень митних правил.

Ключові слова: контрабанда, товари, ввезення, порушення митних правил, митний контроль.

\section{Постановка проблеми у загальному вигляді та ії зв'язок із} важливими науковими чи практичними завданнями. На сьогоднішній день митниця є загально визнаним у світі органом, який забезпечує захист національної економіки. Проте через відсутність фактичного захисту національної економіки вітчизняні товари, за їснуючого на даний час рівня контрабанди, не можуть конкурувати 3 товарами, які завозяться за «чорними схемами» без сплати митних платежів.

Ще у 2018 році Всесвітня митна організація визначила основним трендом для розвитку митниць «надійне бізнес-середовище для економічного розвитку». Ключевим показником економічної безпеки будь-якої держави є іï здатність захищати свій ринок товарів від митних правопорушень. Не дивлячись на те, що Україна після вступу до Світової торгової організації, як і багато інших країн задекларувала курс на лібералізацію торгівлі, вона як і інші держави підвищують рівень захисту своєї економіки.

Одним із основних завдань, покладених на Державну митну службу України є реалізація державної політики у сфері боротьби з контрабандою та правопорушеннями. Проведення заходів із запобігання та протидії контрабанді товарів, боротьби 3 порушеннями митних правил під час здійснення зовнішньоторговельних операцій $\epsilon$ пріоритетним завданням Департаменту організації протидії митним правопорушенням та міжнародної взаємодії Державної митної служби України. Основним акцентом у межах цього завдання $\epsilon$ проведення аналітично-пошукової роботи 3 виявлення способів і механізмів переміщення товарів через митний кордон України 3 порушенням митного законодавства України, а також попередження таких порушень [1].

Виникає необхідність у встановленні чинників, що впливають на зростання обсягів нелегального ринку товарів, та методів i способів потрапляння їх на митні території держав. Незважаючи на значну кількість публікацій, присвячених досліджуваним питанням, теоретичні та практичні аспекти аналітично-пошукової роботи 3 виявлення підстав та схем контрабанди товарів є актуальними та потребують подальшого дослідження. 
Аналіз останніх досліджень, у яких започатковано вирішення проблеми. Окреслення дієвого механізму попередження i подолання контрабанди товарів і митних правопорушень, стає дуже важливим із реформуванням української митниці. Такими вченими-дослідниками, як Яланська О.С., Волошин В.І., Бережнюк І.Г., Смець А.В., Мережко Н.В. розглядалися питання товарної контрабанди, проводилися дослідження порушень митних правил при здійсненні зовнішньоторговельних операцій, окреслювалися проблеми потрапляння контрабандних товарів на ринок Україні та розглядалися питання митної безпеки в аспекті відповідності вимогам законодавства ЄC.

Цілі статті. Важливим $є$ проведення аналізу товарної номенклатури контрабанди і напрямів протидії контрабанді товарів, що переміщуються через митний кордон України в світлі реформування української митниці та окреслити основні вектори протидії.

Об'єкт дослідження. Об'єктом дослідження були групи товарів, завезених за різними контрабандними схемами на митну територію України, основні вектори розвитку діяльності української митниці щодо подолання товарної контрабанди і порушень митних правил.

Методи дослідження. У статті використовувались методи на основі системного аналізу статистичних даних. Для підведення підсумків роботи використовували методи аналізу та синтезу інформації, абстрагування та групування.

Виклад основного матеріалу дослідження 3 повним обгрунтуванням отриманих наукових результатів. Захист економічних інтересів будь-якої країни світу $є$ пріоритетним напрямом державної політики. У загальній концепції розвитку світового ринку товарів визначальними напрямами $\epsilon$ запобігання та протидія контрабанді, забезпечення безпеки державних кордонів, і поряд з тим максимальне спрощення процедур митного контролю i полегшення торгівлі. Угода про спрощення процедур торгівлі державучасниць передбачає спрощення і полегшення міжнародної торгівлі та підвищення загального рівня іiі безпеки.

Нерівнозначна динаміка обсягів контрабандних поставок товарів в Україну свідчить про вплив геополітичних чинників на скоєння злочинів i формування груп організованої злочинності (рис. 1) [2].

Сучасні тенденції формування та розвитку нелегального товарного ринку різних держав світу, зокрема України дають можливість спрогнозувати 
подальше зростання кількості та обсягів завезених контрабандним шляхом товарів (табл. 1) [2, 3].

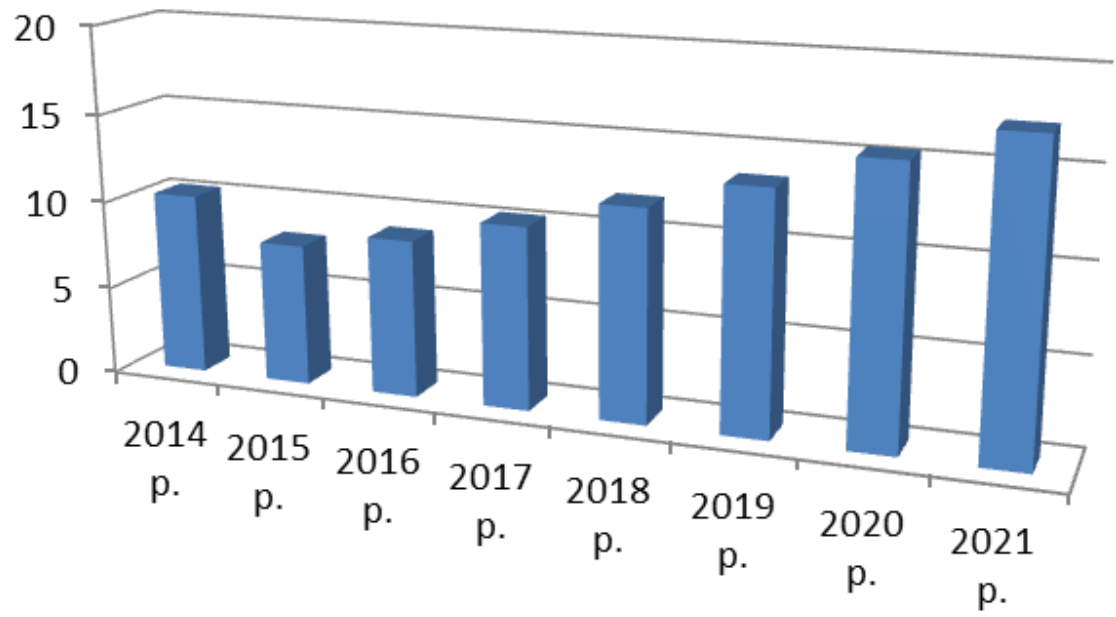

Рис. 1. Обсяги контрабандних поставок в Україну за 2013-2021 рр. (у млрд дол. США, прогноз на 2020 і 2021 р.)

Таблиця 1

Обсяги контрабандних поставок (у млн дол. США) в розрізі окремих товарних груп

\begin{tabular}{|l|c|c|c|c|c|}
\hline \multirow{2}{*}{ Товарна група } & \multicolumn{5}{|c|}{ Роки } \\
\cline { 2 - 6 } & 2017 & 2018 & 2019 & $2020^{*}$ & $2021^{*}$ \\
\hline $\begin{array}{l}\text { Продукти } \\
\text { тваринництва }\end{array}$ & 440,9 & 507,8 & 574,2 & 656,4 & 734,3 \\
\hline Хімічна галузь & 1484,0 & 1709,4 & 1932,6 & 2209,5 & 2471,8 \\
\hline $\begin{array}{l}\text { Харчові } \\
\text { продукти }\end{array}$ & 559,5 & 644,4 & 728,6 & 833,0 & 931,8 \\
\hline Взуття & 273,6 & 315,2 & 356,3 & 407,4 & 455,7 \\
\hline Паливо & 334,8 & 385,6 & 436,0 & 498,4 & 557,6 \\
\hline Всього, \% & 16 & 13 & 11 & 12 & 10 \\
\hline
\end{tabular}

Примітка: * - прогноз Джерело: складено за даними звіту ДФСУ за 2018 рік

Наразі в Україні діє декілька головних схем із завезення товарів контрабандним шляхом.

Перша схема це прикордонна контрабанда, коли мешканці прикордонних населених пунктів щодня їдуть у країни Європейського Союзу, отримують там товар на дозволені законодавством 500 Свро, і везуть його назад. 
Друга схема - посилки з товарами в Україну з крупних світових інтернетмагазинів. Зараз фізична особа може будь-яку кількість раз замовляти товар вартістю до 150 євро без сплати мита.

Третя - класична контрабанда, коли імпортери проводять через митницю за документами один товар, зазвичай дешевий, а насправді везуть у контейнерах - інший, наприклад дорогий брендовий одяг, ювелірні прикраси, техніку тощо. До того ж, часто дорогий одяг потрапляє в Україну під виглядом секонд-хенду. Найбільш популярними схемами «сірого» i «чорного» імпорту, які дозволяють знизити митні платежі $\epsilon$ : чорна контрабанда, перерваний транзит, «норма», заниження ваги, пересорт, товари прикриття, майданчик [8].

Як передбачено Митним кодексом України, товари (крім підакцизних), що переміщуються (пересилаються) на адресу одного одержувача і сумарна фактурна вартість яких не перевищує 150 Євро, не підлягають митному оподаткуванню [6]. Український бізнес сьогодні відчуває проблеми в контексті конкуренції «білого» та «сірого» імпорту, враховуючи масштаби зловживань щодо неконтрольованого ввезення .

Стратегією сталого розвитку “Україна - 2020" в світлі реформ згідно із вимогами євроінтеграції визначено одним з чотирьох пріоритетних векторів розвитку суспільства - вектор безпеки громадян [4]. Потрапляння на митну територію України за різними контрабандними схемами товарів, зокрема харчових продуктів не сприяє розвиткові цього вектору. Так, за даними Державної фіскальної служби у 2017 - 2018 рр. у справах про митні правопорушення було вилучено непродовольчих товарів на суму (млн. грн): 568,6, транспортних засобів - 149,9, харчових продуктів - 119,3 (рис. 2) [2].

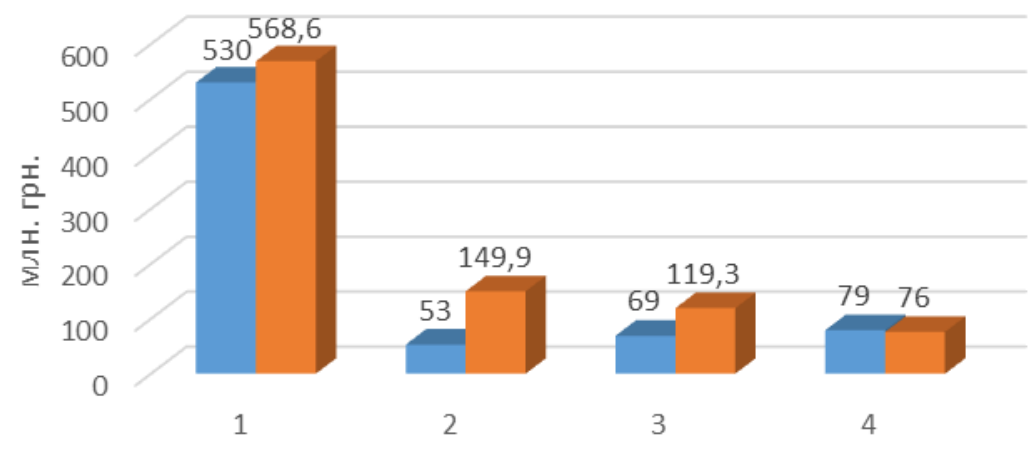

номенклатура тимчасово вилучених товарів у справах про митні правопорушення 


\section{Рис. 2. Номенклатура вилучених товарів у справах про митні} правопорушення: 1 - непродтовари; 2 - транспортні засоби; 3 - харчові

\section{продукти}

А контрабанда наркотичних, психотропних речовин на сьогоднішній день $€$ інтернаціональною проблемою і становить суспільну небезпеку $[8,9]$.

Гучним випадком у 2019 році було виявлення хімічних речовин, що використовуються для виробництва наркотичних засобів, під час перевірки у контейнерному терміналі Одеського порту контейнеру 3 небезпечним вантажем - 28 тонн клею, що прибув з Туреччини. Результати лабораторних досліджень показали, що 7,5 тонн клею містили більше 50\% прекурсорів толуолу і ацетону, які використовуються при виготовленні важких наркотиків, зокрема героїну і кокаїну. Адже саме тому в Україні вони входять до переліку наркотичних засобів, психотропних речовини i прекурсорів, під час пересування яких через митний кордон, якщо масова частка перевищує 50\%, потрібна ліцензія на здійснення діяльності з обігу таких речовин.

У США на судні в порту Філадельфії виявили 16,5 тонн кокаїну на суму, що перевищує 1 млрд доларів США. Це стало найбільшим вилученням наркотиків в історії східного округу Пенсильванії.

Тільки за 2019 рік в Європі вилучили 140 тонн кокаїну, що свідчить про нагальну проблему розроблення заходів попередження контрабанди наркотичних речовин.

Нажаль, непоодинокими є вражаючі факти контрабандного вивезення 3 України товарів, зокрема підакцизних. Як повідомила прес-служба Асоціації «Укртютюн», за даними дослідження міжнародної компанії KPMG, Україна посідає перше місце серед країн, з території яких до Свропейського Союзу поставляються нелегальні сигарети. Тільки у 2018 році 4,2 млрд. сигарет були незаконно ввезені до Свропейського Союзу з митної території України. Зрозуміло, що таке «досягнення» значно шкодить іміджу України на міжнародній арені та знижує іiі інвестиційну привабливість». Асоціація «Укртютюн» також зазначила, що згідно із даними дослідницької агенції Кантар, обсяг нелегального ринку сигарет промислового виробництва в Україні зріс майже у 7 разів з 2016 до 2019 року [5].

Стратегія боротьби з нелегальним ринком сигарет була затверджена у серпні 2017 р. 3 цією метою Кабінет Міністрів України має намір створити єдиний державний реєстр вилучених тютюнових виробів, обладнання, сировини та нетютюнових матеріалів для їх виробництва. Цей крок передбачений відповідно до плану заходів, затверджених 29 січня для 
реалізації стратегії протидії нелегальному виробництву та обігу тютюнових виробів до 2021 року.

Стратегією також передбачено криміналізацію контрабанди тютюнових виробів та запровадження автоматизованої системи контролю за обігом тютюнових виробів відповідно до стандартів ЄС.

3 метою попередження та подолання такого явища як товарна контрабанда застосовують систему аналізу ризику. Згідно із статтею 362 , аналіз ризику - це систематичне використання митними органами наявної у них інформації для визначення обставин та умов виникнення ризиків, їх ідентифікації і оцінки ймовірних наслідків недотримання вимог законодавства України 3 питань митної справи. Одним 3 об’єктів аналізу ризиків є характеристики товарів, що переміщуються через митний кордон України [6]. Необхідність здійснення ефективного митного контролю та митного оформлення зростаючих обсягів товарів, номенклатура яких постійно розширюється, протидія контрабанді та митних правопорушень ставить перед митними органами України нові виклики: впровадження електронної митниця, ризик-менеджменту, авторизація економічного оператора, система NCTS, аналітично-розшукова робота, пост аудит тощо [7].

Висновки та перспективи подальших досліджень. Необхідними заходами слід вважати системне вивчення зовнішньоекономічних операцій, відстеження маршрутів руху товарів, посилення контролю за здійсненням зовнішньоекономічних операцій, аргументовану вибірковість методів і технічних засобів митного контролю на основі системи аналізу ризиків. Впровадження та ефективне застосування в Україні профайлінгу із врахуванням кращих європейських практик може стати ефективним інструментом у запобіганні контрабанди та порушень митних правил. Необхідна підготовка фахівців із спеціальними знаннями про характеристики і властивості товарів, що потенційно можуть бути об'єктом митних правопорушень і контрабанди.

\section{Список використаних джерел}

1. Про затвердження Положення про Департамент організації протидії митним правопорушенням та міжнародної взаємодії Державної фіскальної служби України : Наказ ДФС України від 08.12.2017 р. № 825

2.Звіт Державної фіскальної служби України за 2018 рік [Електронний ресурс]. Режим доступу: http://sfs.gov.ua/data/files/240396.pdf 
3. Аналіз обсягів контрабанди в Україні: масштаби, прямі / непрямі втрати бюджету та економіки - [Електронний ресурс]. - Режим доступу : http://apitu.org.ua/node/119

4. Про стратегію сталого розвитку "Україна - 2020" : Указ Президента України від 12.01.2015 p. № 5/2015[Електронний ресурс]. - Режим доступу: http://http://zakon2.rada.gov.ua/laws/show/1023-12

5. Обсяг нелегального ринку сигарет промислового виробництва зріс майже у 7 разів за останні три роки. - [Електронний ресурс]. - Режим доступу: https://korrespondent.net/ukraine/4188854-ukrayna-stala-lyderom-po-kontrabande-syharet-v-es

6. Митний кодекс України : Закон № 4495-VI // Відомості Верховної Ради України. Редакція 22.09.2019. [Електронний ресурс]. Режим доступу: https://zakon5.rada.gov.ua/laws/show/4495-17/page

7. Про заходи щодо протидії контрабанді та корупції під час митного оформлення товарів : Указ Президента України від 09.07.2019 р. № 505/2019 Електронний ресурс https://zakon.rada.gov.ua/laws/show/505/2019

8. Кукуруза Г., Ніколаєнко С., Лесик М. Основні схеми контрабандних поставок в Україну. Митний брокер. 2019. № 07-08(263) С. 44-52.

9. Передрій О.І., Дзюбинський А.В. Контрабанда наркотичних засобів через митний кордон України. Вісник ЛТЕУ. Технічні науки. 2018. Випуск 21. C. 111-114. DOI: https://doi.org/10.36477/2522-1221-2018-21-18

1. Pro zatverdzhennia Polozhennia pro Departament orhanizatsii protydii mytnym pravoporushenniam ta mizhnarodnoi vzaiemodii Derzhavnoi fiskalnoi sluzhby Ukrainy : Nakaz DFS Ukrainy vid 08.12.2017 r. № 825 [On approval of the Regulation on the Department of Organization of Counteraction to Customs Offenses and International Cooperation of the State Fiscal Service of Ukraine: Order of the State Fiscal Service of Ukraine dated 8.12.2017 No. 825]

2.Zvit Derzhavnoi fiskalnoi sluzhby Ukrainy za 2018 rik [Report of the State Fiscal Service of Ukraine for 2018 ]http://sfs.gov.ua/data/files/240396.pdf

3. Analiz obsiahiv kontrabandy v Ukraini: masshtaby, priami / nepriami vtraty biudzhetu ta ekonomiky [Analysis of smuggling in Ukraine: scale, direct / indirect budget and economic losses]: http://apitu.org.ua/node/119

4. Pro stratehiiu staloho rozvytku "Ukraina - 2020": Ukaz Prezydenta Ukrainy vid 12.01.2015 r. № 5/2015 [On the Sustainable Development Strategy "Ukraine 2020”: Presidential Decree of 5 January 2015 \# 5 / 2015] : http://http://zakon2.rada.gov.ua/laws/show/1023-12

5. Obsiah nelehalnoho rynku syharet promyslovoho vyrobnytstva zris maizhe u 7 raziv za ostanni try roky. [The volume of the illegal cigarette market in industrial production has grown almost 7 times in the last three years] : https://korrespondent.net/ukraine/4188854-ukrayna-stalalyderom-po-kontrabande-syharet-v-es

6. Mytnyi kodeks Ukrainy : Zakon № 4495-VI // Vidomosti Verkhovnoi Rady Ukrainy. Redaktsiia 22.09.2019. [Customs Code of Ukraine: Law No. 4495-VI // Bulletin of the Verkhovna Rada of Ukraine. Revision 09/22/2019] : https://zakon5.rada.gov.ua/laws/show/4495-17/page

7. Pro zakhody shchodo protydii kontrabandi ta koruptsii pid chas mytnoho oformlennia tovariv : Ukaz Prezydenta Ukrainy vid 09.07.2019 r. № 505/2019 [On measures to counteract 
smuggling and corruption during customs clearance of goods: Presidential Decree No. 505/2019 of 09.07.2019] : https://zakon.rada.gov.ua/laws/show/505/2019

8. Kukuruza H., Nikolaienko S., Lesyk M. (2019). Osnovni skhemy kontrabandnykh postavok v Ukrainu. Mytnyi broker. № 07-08(263), 44-52.

9. Peredrii O.I., Dziubynskyi A.V. (2018). Kontrabanda narkotychnykh zasobiv cherez mytnyi kordon Ukrainy. Visnyk LTEU. Tekhnichni nauky. 21, 111-114. DOI: https://doi.org/10.36477/2522-1221-2018-21-18

Цель. Определение факторов, способствующих завозу товаров контрабандным способом с отдельных стран. Определение обстоятельств, которые создают базу для появления рискованных категорий товаров. Установление групп товаров, являюшиеся потенциально опасными в отнотении их попадания на товарный ррынок в разных странах мира контрабандными схемами, что существуют в настоящее время.

Методика. При проведении исследований использовали методьл на основе системного анализа. Для подведения результатов роботы использовали методы анализа и синтеза, абстрагирования и группирования.

Результати. Проанализированные данные контрабандных поставок товаров в разрезе отдельных групп и стран. Представлены данные фактов обнаружения и изъятия контрабандных партий товаров, наркотических средств за последние годы. Обозначены основные схемы завозу товаров в Украину контрабандным путем. представлены факторы влияющие на рост объемов нелегального рынка товаров, методы и способы попадания их на таможенные территории государств. Приведены современные тенденции формирования и развития нелегального рынка разных стран мира, в том числе и Украины.

Научная новизна полученных результатов состоит в критическом анализе способов перемещения товаров через таможенную гранииу и попадание их на товарный рынок разных стран, в том числе Украины. Проведен анализ наиболее распространенных схем ввозу в странь товаров контрабандным путем. Установлень категории товаров, которые становятся чаще всего объектами контрабандных операций.

Практическая значимость состочт в определении проблемных вопросов и установлении совокупности факторов, формирующих потенциальную опасность товарной контрабанды для экономики государства. Означень мероприятия противодействия контрабанде товаров и нарушений таможенных правил.

Ключевые слова: контрабанда, товары, ввоз, нарушение таможенных правил, таможенный контроль.

Purpose. Identification of the factors contributing to the goods contraband from certain countries. Identify circumstances that create the basis for the emergence of risky categories of goods.

Identification of groups of goods that are potentially dangerous for their entry into the commodity market in different countries of the world under current smuggling schemes.

Methodology. The studies used methods based on the systematic analysis of statistics. Methods of analysis and synthesis of information, abstraction and grouping were used to summarize the work. Identification of groups of goods that are potentially dangerous for their 
entry into the commodity market in different countries of the world under current smuggling schemes.

Findings. Data on of goods contraband are analyzed by individual groups and countries. There is data presented on the facts of detection and seizure of contraband lots of goods, drugs in recent years. The main schemes for the importation of goods into Ukraine by smuggling are outlined. The factors that influence the growth of the illegal goods market and the methods and ways of their entering the customs territories of the states are presented. The modern tendencies of formation and development of the illegal commodity market of different countries of the world, in particular Ukraine, are given.

Originality. The scientific novelty lays on the obtained results is a critical analysis of the ways of moving goods across the customs border and their entry into the commodity market of different countries, in particular Ukraine. The analysis of the most widespread schemes of goods contraband to the states is conducted. The categories of goods that are most commonly targeted for smuggling operations have been identified.

The practical value. Practically importance consists of the real situation when there are various problems and sets of factors are established which form the potential danger of commodity smuggling for the economy. There are actions outlined against smugglers and reports on different rules.

Keywords: smuggling, contraband, goods, look, constantly changing rules, customs control

Стаття рекомендована до друку кандидатом технічних наук, доцентом, завідувачкою кафедри товарознавства та експертизи в митній справі Луцьького НТУ Пахолюк О.В. Стаття надійшла в редакиію 20.12.2019 р. 